\title{
Developing Ethical Guidelines for Creating Social Media Technology Policy in Social Work Classrooms
}

\author{
Shane R. Brady \\ David A. McLeod \\ Jimmy A. Young
}

\begin{abstract}
This paper discusses social media technology in the context of social work education. While social media technology is prevalent in social work education, most discourse about the ethical use of social media in the classroom has taken a prescriptive and overly cautious approach that neglects the context-dependent nature that social work educators teach in as well as the overwhelmingly positive potential of social media technology in the classroom. This paper utilizes social constructivist theory and the Competing Values framework to guide the development of an ethical decision-making framework for social work educators to use in order to create dynamic classroom policies related to social media technology. The authors strive to make a modest contribution to the existing literature related to social media technology and social work through the development of this new ethical decision-making framework and discourse related to social media technology, ethics, and social work education.
\end{abstract}

Key Words: Social work education, social media, technology, ethical decision-making

Social media technologies, which include many forms of electronic communication and information sharing, have steadily risen in the U.S. and internationally (Shirky, 2009). These digital communication tools are drastically altering how people interact with one another across space and time (Wesch, 2009). Some have suggested that we are not only living in an era where vast amounts of knowledge are easily accessible to most people through smart phones, tablets, and other portable electronic devices, but also that this trend is changing the nature of how we think about social participation and participatory culture (Jenkins, Clinton, Purushotma, Robison, \& Weigel, 2009; Watwood, Nugent, \& Deihl, 2009). It is the participatory nature of today's digital experience that is most intriguing, and at the same time, anxiety provoking for many social work educators (Bailey \& Johnson, 2014; Schoech, 2013).

Social work education has seen a sharp rise in the attention given to technology and social media in professional practice over the past decade (Hick \& McNutt, 2002; Hoefer, 2012; Young, 2014). During recent years, the Council for Social Work Education (CSWE), the major oversight and regulatory mechanism for social work education in the U.S., has created specialized presentation tracks related to technology in social work (CSWE, 2012). The number of social work professionals and educators using social media sites such as Twitter, Facebook, YouTube, and others to promote cross-cultural and intergenerational communication has grown exponentially (Hitchcock \& Battista, 2013; Young, 2014). Despite the rise in the use of social media technologies, as well as a

Shane R. Brady, PhD, MSW. Assistant Professor, Anne and Henry Zarrow School of Social Work, University of Oklahoma, Norman, OK. Email: srbrady@ou.edu. David A. McLeod, PhD, MSW. Assistant Professor, Anne and Henry Zarrow School of Social Work, University of Oklahoma, Norman, OK. Email: damcleod@ou.edu. Jimmy A. Young, Phd, MSW. Assistant Professor, Department of Social Work, California State University, San Marcos, CA. Email: youngja2@unk.edu

Copyright @ 2015 Advances in Social Work Vol. 16 No. 1 (Spring 2015), 43-54 
greater acceptance of their use in social work practice, many educators are hesitant to make use of these technologies in the classroom, often due to a concern over the lack of ethical guidelines currently available (Seamon, 2013). This paper will help guide social work educators in the development of their own ethical guidelines for social media use in the classroom by helping to identify critical issues and questions that educators should consider when developing social media policy. The goal of this paper is to make a modest contribution to the growing literature of technology and social work by contributing to the discourse on ethical use of social media in social work education.

\section{Social Media Technologies in Social Work Education}

Social media technologies include virtual internet-based communications, applications, and tools that allow the user to interact with others in some way. Social media technologies include well-known and accepted platforms: Facebook, Twitter, LinkedIn, and YouTube, as well as general categories used for the open and social sharing of information such as blogs, Wikis, petition sites, social bookmarks, and document sharing and publishing sites. The defining principle of social media involves applications or tools that allow the creation and exchange of user-generated content (Kanter \& Fine, 2010; Kaplan \& Haenlein, 2010). The wide accessibility of smart phones, tablets, laptops, and other portable electronic devices provides increasing opportunities for individuals to participate with others in digital spaces (DeAndrea, Ellison, LaRose, Steinfield, \& Fiore, 2012). Given the rise of social media use by individuals in the U.S. and globally, it is not surprising that there is also a marked increase in the use of social media by instructors in higher education, including in social work programs (Ahn, 2011; Bennet \& Matont, 2010; Dabbagh \& Kistantas, 2012).

Social work by nature of its professional commitment to advocacy, practice-oriented pedagogy, and social justice is a natural fit for using social media technology in the classroom (Hick \& McNutt, 2002; Robbins \& Singer, 2014). Social work educators have stated that social media is best used in the classroom when it helps students meet learning objectives (Robbins \& Singer, 2014). For instance, Podcasts, Google Hangouts, and Skype are all useful digital tools for exposing students to speakers from around the world and for keeping up with relevant policy topics (Hoefer, 2012). Wikis and blogs are already established tools in social work education for engaging in advocacy, promoting dialogue, and posting resources (Bailey \& Johnson, 2014). Despite the many positive uses of social media in social work education, challenges continue to exist for instructors and institutions (Perron, Taylor, Glass, \& Margerum-Leys, 2010; Reamer, 2013). While issues such as instructor capacity, lack of institutional resources, negative perceptions about social media, and institutional culture are well-documented barriers to using social media in the classroom, the issue of ethical use of social media in social work education has received less attention in the literature (Bailey \& Johnson, 2014; Duncan-Daston, Hunter-Sloan, \& Fullmer, 2013). Much of the existing discourse on ethics and social media usage focuses on the practitioner-client relationship as opposed to the instructorstudent relationship (Mishna, Bogo, Root, Sawyer, \& Khoury-Kassabri, 2012; Perron et al., 2010; Reamer, 2013). Additionally, much of the existing discourse on ethics and social media in social work education takes a very cautious and restrictive approach to 
social media (Duncan-Daston et al., 2013; Hill \& Ferguson, 2014; Kimball \& Kim, 2013). Scholars have made recommendations to social work educators that include only using university-sanctioned learning management systems for social media activities, abstaining from using outside social media, instructing students to maintain only a small personal social network, and recommending that instructors not include students in their social networks (Duncan-Daston et al., 2013). Others suggest that social work educators, practitioners, and students consider the degree that information should be shared, to whom it should be shared, and how the NASW Code of Ethics, institutional, and federal/state policies impact how social media policies in the classroom are constructed (Kimball \& Kim, 2013).

Despite the influx in the use of social media technologies among college students and in the context of higher education, the National Association of Social Workers (NASW) and CSWE provide minimal guidance about ethical use of social media in social work. While the NASW (2005) in partnership with the Association of Social Work Boards (ASWB) created basic guidelines (currently under revision) for the ethical use of technology in social work practice, little focus has ultimately been paid to the ethical use of social media in the context of social work education. Furthermore, technology and social media change at such a rapid rate that what is considered best practice at any give time will likely be outdated quickly, which creates major challenges for the governing bodies of professional social work (Hill \& Ferguson, 2014; Reamer, 2013; Schoech, 2013). In order to contribute to the current discourse on the ethical use of social media and digital technologies in social work education as well as provide some helpful guidance to social work educators, the authors created an ethical decision-making framework rooted in social work values and social constructivism to help educators think through and develop their own policies for guiding social media technology use in the classroom.

\section{Conceptual Framework}

Due to the many differing contexts and complexities impacting social work educators across schools of social work, the authors relied heavily on social constructivism and the Competing Values Framework of policy analysis for guidance on developing the framework proposed in this paper to help instructors think through how to develop classroom social media policy. Often times the topics educators are discussing one day are likely to change by the next, making the act of developing social media policies a challenge for educators and institutions (Aragon, AlDoubi, Kaminski, Anderson, \& Isaacs, 2014). These authors argue that many classroom policies are context dependent, subjective, and often dynamic documents that are best formulated from an interpretive or social constructivist paradigm (Guba, 1990). Using social constructivism as a guiding theory allows for differing policies to be created based upon the contextual factors known at that time and to be adapted as new information becomes available (Biggs, 1996; O'Connor \& Netting, 2008; Stone, 2011). One of the benefits of using social constructivism in policy making is that it acknowledges the subjective values present in decision-making processes, including policy making (Cramer \& Brady, 2013; Quinn \& Rohrbaugh, 1981). 
The Competing Values Framework is the guiding theoretical framework for this paper. The Competing Values Framework emphasizes that various sectors, dimensions, organizations, and individuals involved in policy making often have differing values that may conflict with one another (Cameron, Quinn, DeGraff, \& Thakor, 2007; Quinn \& Rohrbaugh, 1981). These differing values may create tension between entities that strains relationships, growth, and progress (Cramer \& Brady, 2013). Nowhere is the presence of competing values and tension more apparent than in the realm of social media and social work education. While many social work educators view social media as beneficial in promoting social work values, others are concerned that social media use in the classroom could lead to violations of student privacy and confidentiality (Duncan-Daston et al., 2013). The Family Educational Rights and Privacy Act, commonly referred to as FERPA, is the major policy in the U.S. that regulates the classification and sharing of student collegiate records and information (Young, 2014). Many educators view social media threats to student privacy as potentially breaching federal laws such as FERPA, which could cause undo harm to students already in a lower power position in the classroom (Duncan-Daston et al., 2013; Kimball \& Kim, 2013). Since no current frameworks exist for considering ethical decision making and policy development in the classroom from a social constructivist perspective, the authors created the framework below to help instructors think through how to develop a social media technology policy for use in the classroom. Despite the desire and tendency of educators to develop and cling to concrete rules and best practices as they relate to curriculum and policy, it is difficult for such rules to be created with regard to social media usage in social work education as a result of the complexity of factors, values, and tensions that often vary greatly from classroom to classroom, school to school, and institution to institution. Instead, the authors accept the subjectivity and context-dependent nature of ethics in social work education in order to offer educators some critical questions to consider as they think through the development of their own policies related to social media usage in the classroom.

\section{Social Media Technology Policy Framework Explained}

The table below presents a framework of considerations for helping social work educators think through various aspects related to social media technology use in the classroom. The dimensions included in the framework represent some of the major areas that could impact the policy-making process in social work classrooms. Each dimension listed is accompanied by a definition of the dimension, common competing values, and guiding questions that instructors should consider when assessing what is possible and feasible in terms of social media policy in the classroom. 
Table 1: An Ethical Framework for Consideration when Developing Social Media Policies in Social Work Education

\begin{tabular}{|c|c|c|c|c|}
\hline & Instructor Dimension & Student Dimension & Institutional Dimension & Professional Dimension \\
\hline $\begin{array}{l}\text { Dimension } \\
\text { Defined }\end{array}$ & $\begin{array}{l}\text { Values and perspectives held by } \\
\text { social work instructors about social } \\
\text { media, technology, and } \\
\text { teaching/learning that may promote } \\
\text { or hinder the implementation of } \\
\text { social media use in the classroom. }\end{array}$ & $\begin{array}{l}\text { Values and perspectives held by } \\
\text { social work students related to social } \\
\text { media technologies, boundaries, } \\
\text { education, and learning style that } \\
\text { may promote or hinder acceptance of } \\
\text { social media use in the classroom to } \\
\text { varying degrees. }\end{array}$ & $\begin{array}{l}\text { Values, policies, organizational } \\
\text { culture, and capacity of } \\
\text { organizations, schools, departments, } \\
\text { and institutions related to social } \\
\text { media technology use in the } \\
\text { classroom. }\end{array}$ & $\begin{array}{l}\text { Values and ethics related to } \\
\text { professional social work and social } \\
\text { work education (NASW, CSWE) } \\
\text { that could be promoted or } \\
\text { threatened through using social } \\
\text { media in the classroom. }\end{array}$ \\
\hline $\begin{array}{l}\text { Competing } \\
\text { Values }\end{array}$ & Innovation vs. Resistance to change & $\begin{array}{l}\text { Expanded learning milieu vs. Role } \\
\text { confusion }\end{array}$ & $\begin{array}{l}\text { Risk management vs. Student } \\
\text { engagement }\end{array}$ & $\begin{array}{l}\text { Duty to protect vs. self- } \\
\text { determination; social justice vs. } \\
\text { obeying policies; Confidentiality } \\
\text { and perceived privacy vs. } \\
\text { Importance of human relationships } \\
\text { Respect of student autonomy vs. } \\
\text { Access to learning opportunities }\end{array}$ \\
\hline $\begin{array}{l}\text { Guiding } \\
\text { Questions }\end{array}$ & $\begin{array}{l}\text { 1. How do you feel about using } \\
\text { social media in the classroom? } \\
\text { 2. What is your own comfort level } \\
\text { with various social media } \\
\text { technologies? } \\
\text { 3. In what ways do you see yourself } \\
\text { using social media in your } \\
\text { classes, for what purpose, and } \\
\text { with what anticipated learning } \\
\text { outcomes for students? } \\
\text { 4. What concerns do you have about } \\
\text { using social media technologies in } \\
\text { social work classes? } \\
\text { 5. Are your concerns applicable to } \\
\text { the digital world and common } \\
\text { practices in communications } \\
\text { there? }\end{array}$ & $\begin{array}{l}\text { 1. What is your personal comfort } \\
\text { level with social media } \\
\text { technologies? } \\
\text { 2. How do you, if at all, make use of } \\
\text { various types of social media } \\
\text { technology in your own life? } \\
\text { 3. What has been your experience } \\
\text { with using social media in } \\
\text { educational settings? } \\
\text { 4. What concerns do you have, if any, } \\
\text { about having social media used in } \\
\text { a social work class? } \\
\text { 5. Have you ever used or thought } \\
\text { about using social media } \\
\text { technology in the context of } \\
\text { professional social work; if so, } \\
\text { how do you envision using it? }\end{array}$ & $\begin{array}{l}\text { 1. Does your institution, school, or } \\
\text { department have formal policies } \\
\text { related to social media/technology } \\
\text { use in the classroom? } \\
\text { 2. What is the institutional culture } \\
\text { like in regards to social media use } \\
\text { in the classroom? How do your } \\
\text { colleagues and administrators } \\
\text { seem to feel about social media } \\
\text { use in the classroom? } \\
\text { 3. How much of the curriculum for } \\
\text { each class and overall is pre- } \\
\text { determined or mandated by the } \\
\text { school (How much freedom do } \\
\text { you as an instructor have to } \\
\text { revise, change, and create } \\
\text { assignments)? } \\
\text { 4. How much does your institution } \\
\text { use social media technology? }\end{array}$ & $\begin{array}{l}\text { 1. How might some uses of social } \\
\text { media technology in social work } \\
\text { courses potentially violate social } \\
\text { work ethics/policy? } \\
\text { 2. How do you see social media } \\
\text { technologies in social work } \\
\text { classes helping to prepare } \\
\text { professional social workers? } \\
\text { 3. What professional social work } \\
\text { values could be in conflict with } \\
\text { one another in a social media } \\
\text { classroom policy? } \\
\text { 4. How might you negotiate or } \\
\text { resolve these potential conflicts } \\
\text { between professional values in } \\
\text { order to create a useful and ethical } \\
\text { policy for using social media in } \\
\text { the classroom? }\end{array}$ \\
\hline
\end{tabular}


Instructor dimension. The first dimension listed, the instructor dimension, is one of the largest considerations for any educator considering a social media classroom policy. Every social work educator has differing levels of experience and capacity for using social media technology (Gee, 2010). Additionally, instructors vary in their own values and perspectives about the benefits and drawbacks to using social media in the classroom. Often times, instructors may desire to incorporate the use of social media technologies but also may be fearful in regards to student privacy or integrity (Seamon, 2013). Helpful questions in this dimension relate to self-reflection and awareness. Instructors must be able to critically reflect on their own values, perspectives, and beliefs regarding social media and the best use of web-based communications and digital technologies in order to begin considering what is possible and appropriate for their students or within their institutions.

Student dimension. The second dimension provided in the framework above is the student dimension. In developing a social media policy for the classroom, instructors must consider and weigh the benefits of social media for the professional growth of social work students with the potential drawback that students may be confused about the role of social media in the classroom, concerned about boundaries, and unsure of the difference between using social media as a personal tool as opposed to a professional. Instructors working through this dimension to develop social media policy should consider course objectives, learning needs of students, the purpose of using social media technologies, and how social media will be implemented and used in the classroom. Additional consideration should also be given to how instructors will communicate social media policy to students in a clear and deliberate manner.

Institutional dimension. The third dimension proposed in Table 1 relates to the institutional complexities that instructors face. Institutional forces often have significant influence on the policies that social work educators create for their classrooms. Some of the major forces that may influence educators include existing university or institutional policies that have historically been interpreted to dissuade or support social media technology use in the classroom (Reamer, 2013). In some schools, instructors may readily use social media as a mechanism to encourage social participation, while in other schools, there could exist perceptions that social media use is discouraged or policies could exist that restrict the use of social media for learning activities (Perron et al., 2010). The guiding questions posed for the institutional dimension of the framework above are meant to help instructors form a classroom policy in adherence with any existing institutional policies and in line with the culture of the school.

Professional dimension. Lastly, as professional social workers and social work educators, instructors developing social media technology policies for social work courses must be attentive to the various codes of ethics and standards, including, but not limited to, the NASW Code of Ethics, International Federation of Social Workers (IFSW) Code of Ethics, and CSWE Educational Policy and Accreditation Standards (EPAS). When considering ethical codes and professional policies, social work professionals and educators will often find themselves forced to consider two or more values that may potentially conflict with one another (Biggs, 1996; Cramer \& Brady, 2013). For instance, the NASW Code of Ethics specifies that social workers have a duty to promote social 
justice but also to protect the privacy and confidentiality of clients (NASW, 2008). Social work educators must consider the benefits of promoting social work values (e.g., social justice, self-determination), while also considering other values and ethics that could be put at risk (e.g., privacy and confidentiality) through developing social-media-friendly policies for use in the classroom.

\section{Future Directions}

\section{Understanding the Purpose and Scope of FERPA}

One of the most regularly mentioned challenges to instructors and schools implementing more innovative uses of social media technology in classes is anxiety over violating the Family Educational Rights and Privacy Act (20 U.S.C. § 1232g; 34 CFR Part 99). FERPA was originally passed in 1974 as a means to protect the privacy of student education records (U.S. Dept. of Education, 2014). Education records are defined as records such as files, documents, and other materials that directly relate to a student and are maintained by an educational institution (20 U.S.C. § 1232g; 34 CFR Part 99.3). FERPA in higher education protects the privacy of students by regulating what information can and cannot be disclosed, to whom, and for what reasons. Despite providing added protections to the privacy of student information in higher education settings where federal funding is accepted, FERPA does not restrict instructors or institutions from disclosing directory-based information, which commonly includes names, email addresses, addresses, attendance dates, and honors, as long as the school makes students aware of what directory information is kept and shared in a timely manner that allows students to make requests that institutions not disclose their directory information.

FERPA has the potential to provoke anxiety in instructors. In regards to social media technology, many institutions and instructors fear that social media technology not restricted and maintained through university systems (e.g., Blackboard, university advising systems, directories) may create more opportunities for student information to be shared and for privacy to be breached. Despite these common fears, using social media in the classroom is not a violation of FERPA, but how one uses social media may have ramifications for students, instructors, and institutions (Robbins \& Singer, 2014). Additionally, FERPA does not prevent instructors from assigning students the creation of public content as part of their course requirements. FERPA is meant to protect a student's educational records and should not be misconstrued to construct an impermeable barrier between institutions of higher education and the public. While the authors do not profess to have the expertise to provide a legal or formal interpretation of FERPA policy, they do recommend the following helpful FERPA hints: 1) instructors should become more knowledgeable of FERPA through attending institutional training; 2) instructors should consult with their institutional experts about FERPA; 3) instructors should design social media policies as if all students in the class may have requested that directory information be kept private; 4) instructors should consider the potential positive gains as well as potential drawbacks in considering social media policy in the classroom; and 5) 
instructors should provide guidelines in the syllabus regarding how social media is to be used and for what purpose.

\section{Promoting Social-media-friendly Environments in Social Work Education}

One of the areas for future growth in social media technology use and ethical decision making in social work education is creating and promoting social-media-friendly spaces in institutions and classrooms. Several steps can be taken by social work educators to improve the climate for social media technologies in their institutions. Educators can open up greater dialogue about social media technology and ethics in institutions through mechanisms such as formal committees and task groups as well as informal discussions and forums. Additionally, instructors can consider developing interdisciplinary digital learning communities with other departments, schools, and entities within their college or university as well as with other institutions in order to learn and process how to effectively use social media technology in classrooms and institutions. Furthermore, instructors who are successfully using social media technology can partner with colleagues from information technology and related areas to hold trainings geared towards building the capacity of colleagues for using social media technologies. Lastly, the first critical step in creating social-media- and technology-friendly environments in social work education is to advocate to administration in social work schools, departments, and programs to formally commit to engaging in deeper level discussions about social media technology in the classroom.

\section{Developing a Knowledge Base for Social Media Technology in Social Work Education}

Another significant challenge facing instructors, schools, and others in relation to developing effective policies and practices for using social media technology in the classroom relates to the paucity of research and reporting available on social media and social work education. Despite recent contributions made by social work educators, much of the literature related to social media still comes from other disciplines and fields. In order to advance discourse on social media technology in social work education, much more research and dissemination of knowledge is needed to develop informed practice standards or best practices for using social media in social work. More empirical research is needed to better understand how social media technologies are being successfully used in social work education, how social media is impacting student learning of curricular material, and what institutions are doing to embrace social media technologies. The authors recommend that social work educators and institutions using these tools in interesting and innovative ways consider formally evaluating and reporting on their efforts by way of conferences, social media platforms, and formal academic publications to further grow the knowledge base around social media and social work education.

\section{Conclusion}

While the authors each utilize social media differently in social work courses, they are in agreement that there is no ideal, one-size-fits-all classroom policy for social media use. The multitude of factors discussed in this paper and the ethical framework for 
consideration provided help to illustrate the complexity and importance of creating social media technology policies for the classroom. The authors hope to inspire others to create additional frameworks and tools to provide social work educators with additional guidance on utilizing social media and technology in the classroom. While the authors acknowledge the complexities involved in considering professional ethics, formal policies, institutional culture, student learning, and instructor values when developing social media policy for the classroom, they encourage instructors to also consider the benefits and potential of using social media in the classroom. Recently, social media technologies have impacted the rise of social movements and social change in the Middle East, helped to increase dialogue and action related to recent injustices in Ferguson, MO, Florida, and Ohio, and been successfully used to raise millions of dollars for worthy causes, such as in the "Ice Bucket Challenge." Social media has shown to be a powerful tool with significant potential to facilitate communications and actions in social work practice and education.

\section{References}

Ahn, J. (2011). Digital divides and social network sites: Which students participate in social media? Journal of Educational Computing Research, 45, 147-163. doi:10.2190/EC.45.2.b

Aragon, A., AlDoubi, S., Kaminski, K., Anderson, S. K., \& Isaacs, N. (2014). Social networking: Boundaries and limits [Part 1: Ethics]. TechTrends, 58, 25-31. doi:10.1007/s11528-014-0734-9

Bailey, K., \& Johnson, E. J. (2014). Internet-based technologies in social work education: Experiences, perspectives, and use. Caribbean Teaching Scholar, 4, 23-37. Retrieved from

http://journals.sta.uwi.edu/cts/index.asp?action=fullTextPermaLink\&articleid=443\& galleyid=390

Bennet, S., \& Matont, K. (2010). Beyond the 'digital natives' debate: Towards a more nuanced understanding of students' technology experiences. Journal of Computer Assisted Learning, 26, 321-331. doi:10.1111/j.1365-2729.2010.00360.x

Biggs, J. (1996). Enhancing teaching through constructive alignment. Higher Education, 32, 347-364. doi:10.1007/BF00138871

Cameron, K., Quinn, R. E., DeGraff, J., \& Thakor, A. V. (2007). Competing values leadership: Creating value in organizations. North Hampton, MA: Edward Elgar.

Council on Social Work Education. (2012). 2008 Education and policy accredidation standards. Retrieved September 12, 2012, from http://www.cswe.org/Accreditation/2008EPASDescription.aspx

Cramer, E. P., \& Brady, S. R. (2013). Competing values in serving older and vulnerable adults: Adult protective services, mandated reporting, and domestic violence programs. Journal of Elder Abuse and Neglect, 25, 453-468.

doi:10.1080/08946566.2013.782781 
Dabbagh, N., \& Kistantas, A. (2012). Personal learning environments, social media, and self-regulated learning: A natural formula for connecting formal and informal learning. Internet and Higher Education, 15, 3-8. doi:10.1016/j.iheduc.2011.06.002

DeAndrea, D., Ellison, N. B., LaRose, R., Steinfield, C., \& Fiore, A. (2012). Serious social media: On the use of social media for improving students' adjustment to college. Internet and Higher Education, 15, 15-23. doi:10.1016/j.iheduc.2011.05.009

Duncan-Daston, R., Hunter-Sloan, M., \& Fullmer, E. (2013). Considering the ethical implications of social media in social work education. Ethics in Information Technology, 15, 35-43. doi:10.1007/s10676-013-9312-7

Gee, J. P. (2010). New digital media and learning as an emerging area and "worked examples" as one way forward. Cambridge, MA: The MIT Press. Retrieved from http://mitpress.mit.edu/sites/default/files/titles/free_download/9780262513692_New_ Digital_Media.pdf

Guba, E.G. (1990). The paradigm dialogue. Newbury Park, CA: Sage.

Hick, S. F., \& McNutt, J. G. (Eds.). (2002). Advocacy, activism, and the internet. Chicago: Lyceum.

Hill, K., \& Ferguson, S. M. (2014). Web 2.0 in social work macro practice: Ethical considerations and questions. Journal of Social Work Values and Ethics, 11, 2-11. Retrieved from http://www.jswve.org/images/PDFs/2014Spring/2-JSWVE-111Web\%202.0\%20in\%20Social\%20Work\%20Macro\%20Practice-pp\%202-11.pdf

Hitchcock, L. I., \& Battista, A. (2013). Social media for professional practice: Integrating Twitter with social work pedagogy. The Journal of Baccalaureate Social Work, 18, 33-45. Retrieved from http://www.curationculture.org/wpcontent/uploads/2013/10/HitchcockBattista2013_SocialMediaSWK.pdf

Hoefer, R. (2012). Advocacy practice for social justice. Chicago: Lyecum.

Jenkins, H., Clinton, K., Purushotma, R., Robison, A. J., \& Weigel, M. (2009). Confronting the challenges of participatory culture: Media education for the $21^{\text {st }}$ century [White paper]. Retrieved from http://digitallearning.macfound.org/atf/cf/\%7B7E45C7E0-A3E0-4B89-AC9CE807E1B0AE4E\%7D/JENKINS_WHITE_PAPER.PDF

Kanter, B., \& Fine, A. H. (2010). The networked nonprofit: Connecting with social media to drive change. San Francisco, CA: Jossey-Bass.

Kaplan, A. M., \& Haenlein, M. (2010). Users of the world, unite! The challenges and opportunities of social media. Business Horizons, 53, 59-68.

Kimball, E., \& Kim, J. (2013). Virtual boundaries: Ethical considerations for the use of social media in social work. Social Work, 58, 1-4. doi:10.1093/sw/swt005

Mishna, F., Bogo, M., Root, J., Sawyer, J. L., \& Khoury-Kassabri, M. (2012). It just crept in: The digital age and implications for social work practice. Clinical Social Work Journal, 40, 277-286. 
National Association of Social Workers [NASW]. (2005). NASW and ASWB Standards for Technology and Social Work Practice. Washington, DC: NASW Press. Retrieved from http://www.socialworkers.org/practice/standards/naswtechnologystandards.pdf

NASW. (2008). Code of ethics of the National Association of Social Workers. Retrieved from http://www.socialworkers.org/pubs/code/default.asp

O'Connor, M., \& Netting, F. E. (2008). Teaching policy analysis as research: Consideration and extension of options. Journal of Social Work Education, 44, 159173. doi:10.5175/JSWE.2008.200700090

Perron, B., Taylor, H. O., Glass, J., \& Margerum-Leys, J. (2010). Information and communication technologies in social work. Advances in Social Work, 11, 67-81. Retrieved from http://www.ncbi.nlm.nih.gov/pmc/articles/PMC3117433/

Quinn, R., \& Rohrbaugh, J. (1981). A competing values approach to organizational effectiveness. Public Productivity Review, 5, 122-140. Retrieved from www.jstor.org/stable/3380029

Reamer, F. (2013). Distance and online social work education: Novel ethical challenges. Journal of Teaching in Social Work, 33, 369-384. doi:10.1080/08841233.2013.828669

Robbins, S., \& Singer, J. B. (2014). The medium is the message: Integrating social media in social work education. Journal of Social Work Education, 50, 387-390. doi:10.1080/10437797.2014.916957

Schoech, D. (2013). Community practice in the digital age. In M. Weil, M. Reisch, \& M. L. Ohmer (Eds.), The handbook of community practice (pp. 809-826). Thousand Oaks, CA: Sage.

Seamon, J. (2013). Social media for teaching and learning. Boston. Pearson. Retrieved from http://www.pearsonlearningsolutions.com/assets/downloads/reports/socialmedia-for-teaching-and-learning-2013-report.pdf\#view=FitH,0

Shirky, C. (2009). Here comes everybody: The power of organizing without organizations. London, UK: Penguin.

Stone, D. (2011). Policy paradox (3rd ed.). New York: W.W. Norton.

U. S. Department of Education. (2014). Family Educational Rights and Privacy Act (FERPA). Retreived from http://www2.ed.gov/policy/gen/guid/fpco/ferpa/index.html

Watwood, B., Nugent, J., \& Deihl, W. (2009). Building from content to com- munity: [Re] thinking the transition to online teaching and learning [White paper]. Virginia Commonwealth University Center for Teaching Excellence, Richmond, VA.

Wesch, M. (2009). From knowledgeable to knowledge-able: Learning in new media environments. New Media Technologies and the Scholarship of Teaching and Learning. The Academic Commons Magazine. Retrieved from http://www.colorado.edu/ftep/sites/default/files/attached-files/wesch__knowledge_to_knoweldgeable.pdf 
Young, J. (2014). iPolicy: Exploring and evaluating the use of iPads in a social welfare policy course. Journal of Technology in Human Services, 3, 39-53.

doi:10.1080/15228835.2013.860366

\section{Author note}

Address correspondence to: Shane R. Brady, PhD, MSW, Anne \& Henry Zarrow School of Social Work, University of Oklahoma, 700 Elm Avenue, Norman, OK 73019. Email: srbrady78@gmail.com 